\title{
Papua: Sejarah Integrasi yang Diingat dan Ingatan Kolektif
}

\author{
Ester Yambeyapdi \\ Program Studi Pendidikan Sejarah, Fakultas Keguruan dan Ilmu Pendidikan, \\ Universitas Cenderawasih
}

*Alamat korespondensi: e.yyapdi@gmail.com

\begin{abstract}
National integration issue is inherently dynamic and tends to follow the social changes. It is because the problem cannot be taken for granted. This situation is also very dependent on the way and the tendency of a political regime to understand and treat the aspirations of the people in a particular space and time. Based on this matter, this paper analyzes the government's efforts to create national integration in Papua (social, economic, political conditions) and how Papuans interpret the post-New York 1962 integration process, the 1969 Act until the first four years after the Act. Based on the structuralist approach and the theory of political integration, it was found that since Papuans began to adapt to Indonesians, they experienced a new atmosphere, such as the Indonesian government system which is different from the Dutch colonial government. The social, political, and economic life must undergo a period of quarantine which is primarily determined by the interests of the authorities. This situation encourages groups that have certain interests in society. There are Indonesian pro-integration groups, and there are anti-integration groups that manifest themselves in the Free Papua Organization (OPM), and some other social protest movements to date.
\end{abstract}

Diterima/ Received:

25 November 2018

Disetujui/ Accepted: 2 Desember 2018

Keywords: Papua; National Integration; Collective Memory.

\begin{abstract}
Abstrak
Persoalan integrasi nasional pada hakikatnya bersifat dinamis dan cenderung mengikuti arus perubahan sosial. Hal ini disebabkan persoalan tersebut tidak dapat dipandang secara taken for granted. Kondisi tersebut juga sangat bergantung pada cara dan kecenderungan suatu rezim politik memahami dan memperlakukan aspirasi masyarakat pada ruang dan waktu tertentu. Berdasar hal tersebut, tulisan ini bermaksud mendeskripsikan upaya pemerintah dalam menciptakan integrasi nasional di Papua (kondisi sosial, ekonomi, politik) dan bagaimana orang Papua memaknai proses integrasi pasca-New York Agrement 1962, Penentuan Pendapat Rakyat (Pepera) 1969 sampai dengan empat tahun pertama pasca-Pepera. Berdasar pada pendekatan strukturis serta teori integrasi politik, ditemukan bahwa sejak masyarakat Papua mulai beradaptasi dengan orang Indonesia, mereka mengalami suasana serba baru, seperti model pemerintahan yang dipraktikkan oleh pemerintah Indonesia yang sangat berbeda dari pemerintah Kolonial Belanda. Kehidupan sosial, politik, dan ekonomi mengalami masa karantina sangat ditentukan oleh kepentingan penguasa. Kondisi ini mendorong lahirnya kelompok-kelompok yang memiliki kepentingan tertentu di masyarakat. Ada kelompok pro- integrasi Indonesia dan ada kelompok anti-integrasi yang mengejawantah dalam Organisasi Papua Merdeka (OPM), dan sejumlah gerakan protes sosial lainnya hingga kini.
\end{abstract}

Kata Kunci: Papua; Integrasi; Ingatan Kolektif.

\section{Pendahuluan}

Apa yang menjadi motivasi sekelompok orang Papua melakukan demostrasi di berbagai daerah (Papua, Jakarta, Yogayakarta, Surabaya) dan sering kali mengucapkan yel-yel "Papua Merdeka" setelah Reformasi 1998 di Indonesia? Apakah kelampauan Papua "membelenggu" dalam bingkai Negara Kesatuan 
Republik Indonesia? Apakah sejarah integrasi Papua ke dalam NKRI diragukan kebenarannya? Bukankah orang Papua telah dibebaskan dari penjajah Belanda?

Proses integrasi, khususnya integrasi nasional merupakan proses politik yang sangat kompleks karena terkait erat dengan aspek-aspek kehidupan lainnya, seperti sosial budaya dan sistem ekonomi. Kondisi tersebut akan semakin kompleks apabila rakyat berasal dari multietnik dan mendiami berbagai kepulauan seperti masyarakat Indonesia. Hal ini berarti bahwa menguat dan melemahnya integrasi nasional di Indonesia sangat ditentukan oleh perkembangan politik, pertahanan keamanan, ekonomi, dan sosial budaya di dalam negeri (Bahar dan Tangdililing, 1996, pp. 143-144, Pekey, 2018, p. 77).

Provinsi Papua sebagai bagian dari Republik Indonesia, merupakan salah satu wilayah yang rentan terhadap masalah integrasi nasional. Jika diingat sejarah integrasi Papua ke Indonesia, maka wilayah ini berbeda dari wilayah lain di Indonesia yang dalam periode lima tahun sesudah proklamasi 17 Agustus 1945 dapat dibebaskan dari cengkeraman penjajah. Sejarah integrasi Papua mencatat suatu perjuangan yang relatif panjang, yaitu selama lebih kurang 14 tahun, berawal dari Konferensi Meja Bundar 1949 hingga Perjanjian New York 1962 (Pamungkas, 2015, p. 89). Dengan demikian, dapat dipahami bahwa Papua adalah satu-satunya provinsi yang "kembali ke pangkuan ibu pertiwi" melalui Perjanjian New York yang ditandatangani oleh Belanda dan Indonesia pada 15 Agustus 1962. Berdasar isi perjanjian tersebut, pada 1 Oktober 1962, dilakukan penyerahan kekuasaan dari pemerintah Belanda kepada pemerintah Indonesia. Integrasi Papua ke Indonesia juga diperkuat dengan pengakuan Perwakilan Perserikatan Bangsa-Bangsa (PBB), yaitu United Nations Temporary Executive Authority (UNTEA) yang menyerahkan kekuasaan administrasi tersebut kepada pemerintah Indonesia pada 1 Mei 1963 (Huydecoper, 1990, pp. 74-85; Leirissa, 1992, pp. xi, 50-54; Yambeyapdi, 2016, pp. 3945; United Nations, 1963, pp. 273-313)

Pemerintah Indonesia berupaya menanamkan nilai-nilai kehidupan baru yang belum dikenal masyarakat Papua melalui berbagai pendekatan. Agenda terpenting "mengambil hati rakyat" mulai digiatkan dalam masa transisi (1963-1969) di Papua untuk mempermudah pelaksanaan Penentuan Pendapat Rakyat (Pepera) pada 1969. Bersamaan dengan upaya pemerintah RI menanamkan nilai-nilai keindonesiaan, ditemukan pula berbagai penyimpangan sosial yang menimbulkan kekecewaan di hati rakyat. Kekecewaan tersebut semakin terlihat setelah Pepera berlangsung dengan bergabungnya Papua ke dalam negara kesatuan RI (Hendrowinoto, 1998, pp. 68-135; Pemda Irian Barat, 1972, pp. 498-508).

Pada dasarnya, perubahan sosial diakibatkan oleh adanya potensi dari individu atau kelompok untuk mengadakan perubahan atau menentukan nasibnya sendiri. Oleh sebab itu, penelitian ini menggunakan pendekatan strukturis (Lioyd, 1993, pp. 91-100) untuk mengungkap perilaku manusia yang berakar pada struktur sosial individu/kelompok tersebut. Realitas individu (agent) dan struktur sosial (peran, peraturan, interaksi, dan mentalite) yang diperoleh dari sumber sejarah tersebut diharapkan dapat mengukap "causal factor" dalam fenomena integrasi nasional di Papua pada fase peralihan hingga empat tahun pertama pascaperistiwa Penentuan Pendapat Rakyat. Pendekatan strukturis berguna untuk mengungkapkan faktor utama penyebab integrasi nasional di Papua pada masa itu. Kemudian langkah penelitian sejarah dimulai dengan pengumpulan sumber, kritik sumber, analisis sumber, dan eksplanasi kausalitas (Bloch, 1989, pp. 22-25).

Coleman dan Rosberg dalam (Bahar dan Tandililing, 1996, p. 4) menyatakan bahwa proses persatuan bangsa di suatu negara terdiri atas dua dimensi, yaitu: vertikal (elite-massa) dan horisontal (teritorial). Integrasi vertikal mencakup masalah-masalah yang ada dalam bidang vertikal dan bertujuan untuk menjembatani celah perbedaan yang mungkin ada antara kaum elite dan massa 
dalam rangka mengembangkan proses politik terpadu dan masyarakat politik yang berpartisipasi. Integrasi teritorial adalah integrasi dalam bidang horizontal dengan tujuan untuk mengurangi diskontinuitas dan ketegangan kultur kedaerahan dalam rangka proses penciptaan suatu masyarakat politik yang homogen.

Sjamsuddin dalam (Bahar dan Tandililing, 1996, pp. 3-7) pendapat Coleman dan Rosberg tersebut hanya berfokus pada faktor apa yang diintegrasikan. Padahal, terdapat banyak unsur lain yang memengaruhi dan mungkin menentukan adanya celah elit-massa dan perbedaan teritorial. Unsur lain tersebut adalah segi kehidupan manusia yang tidak mengenal batas ruang dan waktu serta batasan lainnya, yakni unsur politik, ekonomi, sosial dan budaya. Dengan demikian, yang terpenting adalah bagaimana faktor-faktor yang ada dalam masyarakat itu menentukan proses tersebut.

Berdasar hal tersebut, tulisan ini mencoba mendeskripsikan sejarah integrasi nasional Papua yang diingat dan menjadi memori kolektif orang Papua. Sebagaimana dikonsepkan oleh Lewis (2014), sejarah tersebut dinamakan "remembered history" atau "sejarah yang diingat". Namun demikian, sejarah dalam arti yang diingat menurut Lewis tidak sepenuhnya dapat dipercaya karena ingatan manusia memiliki keterbatasan. Hal ini turut diperkuat oleh kepentingan tertentu dalam diri manusia. Selain itu, manusia juga memiliki hak untuk mengingat atau melupakan suatu peristiwa (Zuhdi, 2018). Oleh karena itu, tulisan ini menyajikan tiga bagian penting dalam sejarah Papua yaitu situasi Papuas sebelum integrasi Irian Barat, respon masyarakat terhadap upaya integrasi tersebut, serta pelaksanaan Pepera sebagai upaya membangun kepercayaan masyarakat terhadap pemeriintah.

\section{Metode}

Penelitian ini menggunakan metode sejarah untuk menganalisis perkembangan kehidupan sosial politik yang terjadi di Papua pada periode integrasi ke Republik. Proses heuristik dilakukan dengan mengumpulkan sumber primer yang berupa surat kabar (koran), majalah, brosur, laporan-laporan pemerintah, dan laporan gereja serta sumber sekunder yang berupa hasil penelitian yang diterbitkan (buku maupun jurnal) tentang kondisi sosial politik dan ekonomi di Papua pada masa itu. Pencarian data melalui teknik tersebut dilaksanakan di Jayapura. Sementara itu, sumber kajian ini juga didasarkan pada hasil kesepakatan perjanjaian serta kumpulan perundangundangan tentang Papua sebagai daerah otonotmi khusus. Setelah data terkumpul, selanjutnya dilakukan kritik sumber baik secara internal maupun eksternal untuk mendapatkan kredibilitas dan otentisitas. Kemudian data tersebut diinterpretasikan dan siap untuk ditulis sehingga menjadi tulisan utuh dan kronologis.

\section{Kondisi Papua Sebelum 1 Mei 1963}

Papua merupakan salah satu daerah di Indonesia yang kembali ke dalam negara Kesatuan Republik Indonesia atas intervensi Perserikatan Bangsa-Bangsa. Realitas penjajahan yang dilakukan Belanda di daerah Papua amat berbeda dari daerah lain di Indonesia. Sebagai contoh, di Jawa rakyat menjalani praktik kerja-paksa, penyiksaan, dan kematian akibat ulah penjajah Belanda di Hindia Belanda, maka di Papua tidaklah demikian. Bagi masyarakat, Belanda bukanlah penjajah. Kehadiran Belanda di Papua bertujuan untuk misi penyebaran Injil dan misi kemanusiaan lainnya (Mashad \& Ikrar, 2001; Ikrar, 1996, pp. 219-224).

Pengalaman rakyat Papua ketika beradaptasi dengan orang Indonesia, sesuai kesepakatan New York 1962, relatif amat berbeda. Sejak awal, orang Papua menyaksikan bagaimana perilaku yang ditunjukkan oleh para aparat militer dan sipil Indonesia ketika itu (Pemda Irian Barat, 1972, pp. 498-508; Yambeyapdi, 2016). 
Masa pemerintahan Badan Perwalian Perserikatan Bangsa-bangsa, United Nations Temporary Executior Authority (UNTEA) yang relatif singkat (Oktober 1962 s.d. April 1963) mengakibatkan UNTEA belum dapat merealisasikan kebijakan pembangunan yang telah diagendakan. UNTEA lebih menekankan kebijakan pada menjaga keamanan di Papua. Akibat demonstrasi massa, UNTEA melalui Dr Djalal Abdoh, kemudian menyerahkan kekuasaan pada pemerintah Indonesia pada 1 Mei 1963 (The Liang Gie dan Soegeng, 1968, pp. 57-60; Drooglever, 2010, pp. 613-630).

\section{Reaksi Masyarakat Memaknai Integrasi Nasional}

Pemberontakan Organisasi Papua Merdeka (OPM) yang meletus sejak 26 Juli 1965 merupakan cerminan nyata masalah integrasi nasional. Gerakan yang dimulai dari Manokwari ini dipimpin oleh Serma Permenas Ferry Awom, mantan Anggota Batalyon Sukarelawan Papua (Papua Vrijwillegers Korps) bentukan Belanda (Sjamsuddin, 1989, pp. 90-100; Rianda, 2017, pp. 92-93).

Jika dicermati, meletusnya gerakan separatis OPM disebabkan oleh keterbatasan komunikasi, khususnya dalam arti politik. Padahal, komunikasi merupakan hal pokok yang diharapkan dapat memberi efek terhadap pengalaman politik atau proses sosialisasi politik bagi masyarakat Papua. Hal tersebut karena kala itu (masa kolonial Belanda), pendidikan masyarakat Papua sangat terbatas, sehingga berpengaruh pada minimnya kualitas proses komunikasi dengan gerakan nasionalis di luar Papua. Perlu dicatat bahwa masyarakat Papua tidak pernah mengenal adanya semangat Sumpah Pemuda 1928 (Djopari, 1993, pp. 100-151; Ikrar, 1996, pp. 224-226).

Kemelut ekonomi dan politik Indonesia di era 1960an juga memiliki andil dalam memahami kondisi sosial-ekonomi Papua pada masa itu. Keadaan ekonomi Indonesia sendiri kala itu mengalami kemunduran, sehingga sektor pertama yang diperhatikan adalah pembangunan administrasi daerah, pendidikan formal, dan pelayanan kesehatan. Untuk melakukan ketiga hal itu, terlebih dahulu dilakukan penyesuaian nilai mata uang dan harga barang di masyarakat. Meski pada 1962-1968 ekonomi di Indonesia pimpinan Soekarno mundur drastis ditandai dengan gejala hiperinflasi tidak terkendali, nilai uang Papua (sisa pengelolaan ekonomi Belanda yang jauh lebih tinggi) masih dapat bertahan sampai dengan lima tahun setelah bergabung dengan Indonesia. Proses penyesuaian itu terhambat sampai tujuh tahun karena alasan situasi politik pemerintah dengan Malaysia. Namun demikian, pada 1971, proses penyesuaian nilai uang rupiah Papua dan Indonesia selesai, sehingga pembangunan secara nyata baru dapat dimulai (Hendrowinoto, 1998).

Sementara pada saat yang sama, pegawai pemerintah dan orang Indonesia lain yang ditempatkan di Papua atau bermigrasi swakarsa bertingkah laku sangat kurang baik dengan memanfaatkan perbedaan nilai mata uang serta persediaan barang impor di Papua demi keuntungan pribadi. Hal ini justru terjadi ketika penduduk asli Papua mulai belajar mengenal saudaranya yang baru setanah air. Persoalan lain muncul terutama berkaitan dengan materi yang didogmakan pada masyarakat bahwa Indonesia termasuk Papua karena dijajah Belanda selama 350 tahun yang membawa implikasi kemiskinan dan ketertindasan. Padahal, konsep miskin dan tertindas bagi rakyat Papua dalam kaitan dengan kolonial Belanda jelas tidak tepat, mengingat Belanda saat di Papua telah mengubah sistem penjajahannya, sehingga Papua tidak mengalami kondisi seperti yang dialami daerah lain (Mashad dan Ikrar, 2001; Yambeyapdi, 2016).

Akibat kebijakan Indonesia yang terkesan kurang peduli terhadap Papua, sebagian masyarakat diam-diam atau pun terang-terangan akhirnya mendukung OPM. Pemerintah Indonesia mulai dipandang sebagai penjajah baru, yang merefleksikan dari tindakan kesewenangan oknum aparat pemerintah sipil atau militer, seperti pengambilan paksa barang yang ditinggalkan Belanda atau 
memanfaatkan isu tuduhan terlibat OPM untuk membenarkan tindakan tidak terpuji aparat (Ikrar, 1996, pp. 223; Rianda, 2017; Elisabet, 2006, pp. 44-45).

\section{Pelaksanaan Pepera 1969 dan Upaya Membangun Kepercayaan Masyarakat}

Sebagai realisasi terakhir dari Persetujuan New York, selain masalah UNTEA, serta peralihan Papua ke tangan RI 1963, ditetapkan bahwa selambat-lambatnya pada 1969 sudah harus melaksanakan Act of Free Choice. Hal ini menunjukkan bahwa masalah Papua secara normatif (hukum international) berakhir sejak akhir 1969. Kondisi ini menjadi gambaran suasana Penentuan Pendapat Rakyat (Amirmahmud, 1987, pp. 333-339; Saltford, 2003, pp. 158-177).

Episode terakhir pertikaian Papua terjadi di Majelis Umum PBB pada 19 November 1969, ketika rancangan resolusi gabungan dari RI dan Belanda diterima dengan 84 suara mendukung, tidak ada yang menolak, sedangkan 30 abstain. Besarnya jumlah yang abstain tentu sangat mengherankan, karena sebagian besar berasal dari negara-negara Afrika. Mereka yang meski secara umum mendukung kembalinya wilayah itu ke RI, tetap keberatan pada fakta bahwa prinsip "satu orang, satu suara" tidak tercakup di dalam "tindakan pilihan bebas". Sebagai gantinya, pemerintah Indonesia memutuskan untuk memberikan pilihan itu di tangan delapan dewan konsultatif, yang para anggotanya dipilih lewat musyawarah. Ini berarti bahwa para kepala suku dan para pemuka masyarakat lainnya, yang mayoritas masih buta huruf memiliki keputusan. Hasilnya dapat diperkirakan, seperti dilaporkan Sekjen, jawaban dewan-dewan konsultatif seragam, yaitu Papua tetap bergabung dengan RI. (Amirmahmud, 1987; Drooglever, 2010, pp. 744-750; Pekey, 2018, pp. 92-93)

Sehubungan dengan tindakan pemilihan bebas tersebut, Menteri Luar Negeri Indonesia, Adam Malik, mengatakan bahwa "mudah mengkritik penerapan suatu ujian politik yang sulit bahkan kontroversial dan itu memang kasus mengenai pengaturan untuk mengadakan pilihan bebas, khususnya jika hendak memakai tindakan yang disebut standar internasional, yang biasanya berarti penerapan standar-standar Barat pada kondisi dan situasi di Asia. Standar itu tidak sesuai diterapkan di daerah ini. Apalagi bagi Papua yang dikenal sebagai salah satu wilayah terbelakang, seseorang harus memiliki pertimbangan-pertimbangan tertentu bagi keadaan-keadaan di Papua" (Amirmahmud, 1987; Saltford, 2003).

Terciptanya pernyataan penduduk Papua untuk tetap bergabung dengan Indonesia merupakan hasil usaha Amirmahmud, selaku wakil Indonesia yang melaksanakan tugas Pepera. Usaha tersebut telah ditulis dalam otobiografinya, bahwa ketika ia menerima tugas tersebut ia tidak pernah mempertanyakan status Papua. Baginya, wilayah itu telah menjadi bagian dari Indonesia dan akan tetap demikian. Saat menyusun programnya, ia selalu dihantui oleh kemungkinan, bagaimana dan tindakan apa yang akan dilakukan kalau mayoritas rakyat Papua memilih melepaskan diri dari Republik Indonesia. Bagi pemerintah Indonesia, Papua Barat harus tetap dalam wilayah kekuasaan Indonesia sehingga dalam praktikpraktik Pepera menurutnya, cara-cara yang ia gunakan dianggap kurang sesuai dengan hukum internasional. Selain itu, saat perjalanan peninjauan daerah-daerah di Papua, sebelum Pepera, Amirmahmud juga menyaksikan bahwa bagian terbesar dari penduduk di wilayah itu memang belum sadar politik, sehingga dalam Pepera wakil-wakil penduduk cukup mengatakan kata seperti, "Suharto", "Merah Putih", atau "Republik Indonesia." Meskipun demikian, dalam laporannya setelah kembali dari peninjauan Pepera, dikatakan bahwa "kenyataan menunjukkan sebagian terbesar dari penduduk tidak simpati kepada RI" (Amirmahmud, 1987).

Setelah Papua resmi menjadi bagian dari Negara Kesatuan Republik Indonesia melalui Pepera, maka pemerintah segera melakukan pembenahan pembangunan di Papua. Menurut Hendrowinoto (1998), penulis biografi Acub 
Zainal, ketika Acub Zainal menjadi Pangdam XII Cenderawasih, ia menerapkan sejumlah kebijakan, di antaranya "operasi koteka" dan pembangunan infrasruktur. Upaya pembangunan lebih giat dilakukan ketika ia diangkat sebagai gubernur Papua (1973). Segala upaya itu dilakukan dengan tujuan untuk membangkitkan kepercayaan masyarakat terhadap pemerintah Indonesia serta aparat bersenjata. Namun akibat kebijakan yang telah dilakukan, ia diberhentikan dari jabatan sebagai gubernur dan sekaligus mengakhiri karier militernya (Hendrowinoto, 1998).

Dengan demikian, dapat dipahami bahwa pembangunan di Papua secara nyata baru dinikmati rakyat pascaintegrasi 1969. Sebelumnya, rakyat diperintah dalam kondisi seolah dikarantina. Artinya, setelah New York Agreement diratifikasi pada 1962, seluruh kehidupan sosial, politik, dan ekonomi rakyat Papua sangat ditentukan oleh pemerintah Indonesia. Kondisi itu tentu saja turut berdampak terhadap persoalan integrasi politik Papua yang mengejawantah dalam Organisasi Papua Merdeka dan sejumlah gerakan perlawanannya.

\section{Simpulan}

Sejak United Nations Temporary Executive Authority (UNTEA) menyerahkan Papua kepada pemerintah Negara Kesatuan Republik Indonesia pada 1 Mei 1963, sampai saat ini, daerah Papua tetap menyimpan segudang masalah yang rumit, khususnya berkaitan dengan keamanan. Pemerintah Indonesia mulai menerapkan berbagai kebijakan pembangunan dalam berbagai sektor sebagai upaya menumbuhkan kesadaran nasional. Namun akibat keterbatasan ekonomi dalam negeri Indonesia, maka kebijakan pembangunan yang dilakukan hanya pada bidang sosial, keamanan, dan politik.

Situasi sosial, ekonomi, dan politik Papua antara 1963 sampai dengan 1969 menjadi kondisi yang sangat memilukan bagi masyarakat. Karena di saat mereka mengalami status karantina, mereka menyaksikan pegawai pemerintah dan orang Indonesia lain yang ditempatkan di Papua berperilaku sangat kurang terpuji. Mereka melakukan "perampokan terbuka". Selain itu, ada pula yang memanfaatkan perbedaan nilai mata uang serta persediaan barang impor di Papua demi keuntungan pribadi. Hal ini justru terjadi ketika penduduk asli Papua perlu belajar mengenal saudara yang baru, saudara setanah air. Ekspresi kekecewaan masyarakat ini secara ekstrim muncul dalam Organisasi Papua Merdeka (OPM) yang meletus sejak 26 Juli 1965.

\section{Referensi}

Amirmahmud. (1987). H. Amirmahmud, prajurit pejuang, otobiografi. Jakarta: Panitia Penerbitan Otobiografi Bapak H. Amirmahmud.

Bahar, S., \& A.B. Tandililing. (Ed.). (1996). Integrasi nasional: teori, masalah dan strategi. Jakarta: Ghalia Indonesia.

Bloch, M. (1989). Pledooi voor de geschiedenis of geschiedenis als Ambach, Nederlandse vertaling. Nijmegen: SUN.

Djopari, J. RG. (1992). Pemberontakan Organisasi Papua Merdeka. Jakarta: PT Gramedia.

Drooglever, P.J. (2010). Tindakan pilihan bebas orang Papua dan penentuan nasib sendiri. Yogyakarta: Kanisius.

Elisabet, A. (2006). “Dimensi internasional kasus Papua. Jurnal Penelitian Politik. Vol. 3. No. 1. Jakarta: LIPI. pp. 44-45.

Hendrowinoto, N. K. S. (1998). Acub Zainal: I love the army. Jakarta: Pustaka Sinar Harapan.

Ikrar N. B. (1996). “Tinjauan empiris integrasi nasional Irian Jaya: aspek internasional", dalam Bahar, S., \& A.B. Tandililing. (Ed.). Integrasi nasional: teori, masalah dan strategi. Jakarta: Ghalia Indonesia. 
Leirissa, R.Z. ( Ed.). (1992), Sejarah proses integrasi Irian Jaya. Jakarta: DepdikbudDisjara Projek Inventaris dan Dokumen Sejarah Nasional.

Lewis, B. (2014). Sejarah diingat, digali, ditemuciptakan (Terjemahan). Yogyakarta: Ombak.

Lioyd, C. (1993). The structures of history. British: Blackwell Oxford.

Mashad, D. \& Ikrar N. B. (2001). Berbagai faktor separatisme di Irian Jaya", dalam Indonesia di ambang perpecahan?: Kasus Aceh, Riau, Irian Jaya, dan Timor-Timur. Jakarta: Erlangga.

Nigtevecht, Jhr.Mr.JLR. H. van. (1990). Nieuw Guinea, her einde van een Koloniaal beleid. s- Gravenhage,: SDU Uitgeverij.

Pamungkas, C. (2015). Sejarah lisan integrasi Papua ke Indonesia: Pengalaman orang Kaimana pada masa Trikora dan Pepera, Paramita Historical Studies 25, 1, 88108. https: / / doi.org/10.15294/ paramita.v25i1.3423.

Pekey, F. (2018). Papua mencari jalan perdamaian, telaah konflik dan resolusi di bumi Cenderawasih. Jakarta: Penerbit Buku Kompas.

Pemda Propinsi Irian Barat. (1972). Penentuan pendapat pakyat (Pepera) di Irian Barat 1969. Djajapura.

Rianda, B. Yuswari O. D. dan Angga N.R. (2017). “Kebijakan luar negeri Indonesia terhadap dukungan Republik Vanuatu atas kemerdekaan Papua Barat tahun 2015-2016". Dinamika Global. Vol. 02, No. 01. Juni 2017. pp. 82-113. Cimahi: Fakultas Ilmu Sosial dan Ilmu Politik Unjani.

Saltford, J. (2003). The United Nations and The Indonesian takeover of West Papua, 19621969. London and New York: RoutledgeCurzon, Taylor \& Francis Group.

Sjamsuddin, N. (1989). Integrasi politik di Indonesia. Jakarta: PT. Gramedia.

The Liang Gie \& F. Soegeng Istanto. (1968). Pertumbuhan Pemerintahan Propinsi Irian Barat dan kemungkinan-kemungkinan perkembangan otonominya di hari kemudian, Jilid I. Yogyakarta: Seksi Penerbitan Fakultas Sosial dan Politik Universitas Gadjah Mada.

United Nations (1963). Treaty series, treaties and international agreements registered or filed and recorded with the secretariat of the United Nations. Vol. 437. New York.

Yambeyapdi, E. (2016). Ten years of Papua integration with the Republic of Indonesia from 1963 to 1973. Australian Journal of Basic and Applied Sciences, 10, 9, 39-45.

Zuhdi, S. (2018). "Kesultanan bacaan, ingatan kolektif, dan rekonstrksi sejarah kontemporer Indonesia", dalam Rahayu Surtiati Hidayat (Ed.) Hakikat ilmu pengetahuan budaya. Jakarta: Yayasan Pustaka Obor Indonesia. 